\title{
Effect of Propagation Methods on Yield Attributes and Economics of Ginger Production under Agro-Climatic Condition of Tripura
}

\author{
S. Shil ${ }^{*}$, D. Nath ${ }^{2}$ and J. Mondal ${ }^{3}$ \\ ${ }^{1}$ SMS (Horticulture), KVK Khowai, Tripura, India \\ ${ }^{2}$ KVK Khowai, Tripura, India \\ ${ }^{3}$ Department of CIHAB, P.S.B., Visva-Bharati, Sriniketan, India \\ *Corresponding author
}

\section{A B S T R A C T}

\section{Keywords \\ Ginger, Agro- climatic condition, Spice crop \\ Article Info \\ Accepted: \\ 30 April 2018 \\ Available Online: \\ 10 May 2018}

\begin{abstract}
Ginger, an indigenous plant, is an important spice crop of the world. Traditionally ginger is propagated by using portions of mother rhizomes called as sets. Each healthy set of 2.5 to $5 \mathrm{~cm}$ long, weighing 20-25 g and having two or three buds each are directly sown in the main filed. Though transplanting in ginger is not conventional, it is found profitable. A transplanting technique in ginger by using single bud sprouts (about $5 \mathrm{~g}$ ) has been standardized to produce good quality planting material with reduced cost. The yield level of ginger transplants is on-par with conventional planting system. Also it is observed that the requirement of seed material per ha is reduced to $600 \mathrm{~kg}$ in transplanting method in comparison with conventional methods which is $2000 \mathrm{~kg} / \mathrm{ha}$. The advantages of this technology are production of healthy planting materials and reduction in seed rhizome quantity and eventually reduced cost on seeds.
\end{abstract}

\section{Introduction}

Ginger, an indigenous plant, is an important spice crop of the world. It is valued in medicine as a carminative and stimulant of the gastro-intestinal tract. The botanical name of ginger is Zingiber officinale L. which belongs to the family Zingiberaceae. Ginger is a herbaceous perennial with underground rhizomes having serial leafy shoots of 0.5 to $0.75 \mathrm{~m}$ height; leaves sheathy, alternately arranged, linear with $15 \mathrm{~cm}$ long and sessile flowers borne on a spike, condensed, oblong and cylindrical with numerous scar bracts; flowers numerous yellow in colour with dark purplish spots, bisexual, epigynous, stamens only one, ovary inferior, three carpelled; fruit an oblong capsule, seeds glabrous and fairly large. India and accounts for $45 \%$ of the worlds ginger production. Mainly grown in Kerala and on very small area in Karnataka, Tamil Nadu, West Bengal, Bihar, Himachal Pradesh, Uttar Pradesh and Maharashtra. Area under cultivation in India is about 63,000 ha. with total production of about 2 lakh tones. The average productivity is about 5 tones/ha. The North Eastern Region produces a variety of spices including chillies, ginger, turmeric, large cardamoms, black pepper, tejpatta etc. Ginger and turmeric are prominent among them and their cultivation is under taken as a cash crop mostly in jhum fields spread over 
the hills and tribal areas of the entire region. The total area under ginger cultivation in Tripura is about 1.36 ('000 ha) with total production of about 5.45 thousand tones. Ginger is grown in almost all the states of the region but the leading states are Meghalaya, Mizoram, Arunachal Pradesh and Sikkim (Govind et al., 1998). Apart from improved varieties like Nadia, China, Varada, etc., a number of local cultivars exist in northeastern region. But the area under ginger cultivation in Tripura is reducing day by day. Among Different constrains Non-availability of quality planting material is another important factor attributing to low productivity. Moreover, in case of Conventional propagation method (direct sowing) of ginger the cost planting material (seed) is approximately $70 \%$ of the total cultivation cost. So, to reduce the cost of planting material a technique has been developed by the Spice Board of India where ginger is propagated through raising seedlings. And such materials at low cost are technically feasible in slope areas and are eco-friendly substances. Considering the entire situation the experiment has been set to find the suitability of the technique in Tripura condition.

\section{Materials and Methods}

In the instructional farm of KVK, Khowai, "Tripura an experiment on "Effect of propagation methods on yield attributes and economics of Ginger production under agroclimatic condition of Tripura" has been conducted during the year 2013-14, 2014-15, 2015-16. And treatment comprises of $\mathrm{T} 1$ : Single bud transplanting, T2: 20-25 g direct planting.

\section{Propagation}

Direct seeded /planting method (T1) Transplanting method (T2)

\section{Direct planting method}

Traditionally ginger is propagated by using portions of mother rhizomes called as sets. Each healthy set of 2.5 to $5 \mathrm{~cm}$ long, weighing 20-25 g and having two or three buds each are directly sown in the main filed.

Before planting the seed rhizomes should be treated with Dithane M-45 @ 3 g per liter of water for 30 minutes, drained and then used for planting.

\section{Transplanting technology}

Though transplanting in ginger is not conventional, it is found profitable. A transplanting technique in ginger by using single bud sprouts (about $5 \mathrm{~g}$ ) has been standardized to produce good quality planting material with reduced cost.

The technique involves raising transplants from single sprout seed rhizomes in the protray and planted in the field after 30 days.

Selection of healthy rhizomes of ginger for seed purpose, Treat the selected rhizome with mancozeb $(0.3 \%)$ and quinalphos $(0.075 \%)$ for $30 \mathrm{~min}$ and store in well ventilated place till planting. At the commencement of season, cut the single buds with small piece of rhizomes weighing 4- $6 \mathrm{~g}$. Treat the single bud sprouts (mancozeb $0.3 \%, 3 \mathrm{~g} / \mathrm{L}$ of water for 30 min) before planting.

Fill the pro-trays (98 well) with nursery medium containing partially decomposed coir pith and vermicompost (75:25), enriched with PGPR/Trichoderma $10 \mathrm{~g} / \mathrm{kg}$. If coir pith is not available farmer can use sand, soil, vermicompost @ 1:1:1 ratio to fill the protrays. Plant the ginger bud sprouts in protrays. Maintain the pro-trays under shade net house. Seedlings will be ready within 30-35 days for transplanting. (Prasath et al., 2016). 


\section{Manures and Fertilizers}

\begin{tabular}{|c|l|c|c|c|c|}
\hline SI. No. & Time of application & $\begin{array}{c}\text { F.Y.M. } \\
\text { (ton/ha) }\end{array}$ & $\begin{array}{c}\mathbf{N} \\
\text { (kg/ha) }\end{array}$ & $\begin{array}{c}\mathbf{P}_{2} \mathbf{O}_{5} \\
(\mathbf{k g} / \mathbf{h a})\end{array}$ & $\begin{array}{c}\mathbf{K 2 0} \\
\text { (kg/ha) }\end{array}$ \\
\hline 1. & Preparatory tillage & 15 & - & - & - \\
\hline 2. & At planting & 15 & 60 & 50 & 50 \\
\hline 3. & 45 days after planting & - & 50 & - & - \\
\hline 4. & 120 days after planting & - & 40 & - & - \\
\hline & Total & 30 & 150 & 50 & 50 \\
\hline
\end{tabular}

Table.1 Fresh yield of ginger as affected by propagation technique

\begin{tabular}{|l|l|l|l|l|} 
& \multicolumn{3}{|l|}{ Yield (fresh rhizomes) ('000 t) } & \\
& $2013 / 14$ & $2014 / 15$ & $2015-16$ & Mean \\
\hline T1 (Single bud transplanting) & 4.45 & 4.35 & 4.43 & 4.41 \\
\hline T2 (20-25 g direct planting) & 4.51 & 4.53 & 4.46 & 4.50 \\
\hline CD (5\%) & NS & 0.95 & 0.84 & \\
\hline CV (\%) & 20.14 & 21.11 & 18.23 & \\
\hline
\end{tabular}

Table.2 Economics of ginger cultivation

\begin{tabular}{|c|c|c|}
\hline Cost of seedling production & $\begin{array}{l}\text { Pro-tray } \\
\text { nursery }\end{array}$ & $\begin{array}{l}\text { Conventional } \\
\text { planting }\end{array}$ \\
\hline Temporary structure for shade (150 m2) & 7000.00 Rs. & - \\
\hline $\begin{array}{l}\text { Seedling production cost } \\
(\sim 100000 \text { seedling/ha; } 1200 \text { protrays, Rs.16/pro-tray, } \\
\text { reusable @ Rs.8/tray, labour cost for raising seedling } \\
\text { (15 nos @ Rs.300/ head) }\end{array}$ & 14100.00 Rs. & - \\
\hline $\begin{array}{l}\text { Cost of growing media } \\
\text { (cocopeat, vermicompost, trichoderma) }\end{array}$ & 7000.00 Rs. & - \\
\hline $\begin{array}{l}\text { Cost of seed rhizome } \\
(600 \mathrm{~kg} @ \mathrm{Rs.80} / \mathrm{kg}) \\
(2000 \mathrm{~kg} @ \mathrm{Rs} .80 / \mathrm{kg}) \\
\end{array}$ & $\begin{array}{l}48000.00 \text { Rs. } \\
-\end{array}$ & $160000.00 \mathrm{Rs}$ \\
\hline $\begin{array}{l}\text { Labour charges } \\
\text { (For Field Preparation, Planting and maintenance } 25 \\
\text { nos. @ Rs.300/ head) }\end{array}$ & 7500.00 Rs. & 7500.00 Rs. \\
\hline $\begin{array}{l}\text { Cost of Other inputs (Fertilizer, Plant protection } \\
\text { chemicals, etc) }\end{array}$ & 5000 Rs. & 5000 Rs. \\
\hline Gross Cost & 88600 Rs. & 172500 Rs. \\
\hline Average yield /ha & $4410 \mathrm{~kg}$ & $4500 \mathrm{~kg}$ \\
\hline Gross income & 352800 Rs. & 360000 Rs. \\
\hline Net income & 264200 Rs. & 187500 Rs. \\
\hline Benefit Cost Ratio & 2.98 & 1.08 \\
\hline
\end{tabular}




\section{Results and Discussion}

From the data presented in the above table 1 it is observed that in all the subsequent year the yield level of ginger transplants is on-par with conventional planting system. That is there is no significant difference in yield in case of both the treatment. This finding can be corelated with the finding of Jayashree et al., (2015).

From the data presented in the above table 2 it can be revealed that the requirement of seed material per ha is reduced to $600 \mathrm{~kg}$ in transplanting method in comparison with conventional methods which is $2000 \mathrm{~kg} / \mathrm{ha}$. And that's make huge difference in the cost of cultivation and ultimately to the net income. From the above data we can calculated the cost of individual seedling is 0.69 paise.

So, we can conclude that the advantage of T1 (20-25 g direct planting) are production of healthy planting materials and reduction in seed rhizome quantity, reduced cost on seeds and eventually increase the net profit as there no significant difference yield in both the treatment.

\section{References}

Jayashree, E., Kandiannam, K., Prasath, D., Rashid, P., Sasikumar, B., Senthilkumar, C.M., Srinivasan, V., Suseela, B. R., and Thankamani, C.K. (2015). ICAR-Indian Institute of Spice Research, Kozhikode Kerala. Pp. 1-15

Prasath, D., Kandiannan, K., Srinivasan, V and Aanandaraj, M. (2016). Spice India. Improved propagation techniques in ginger and black pepper. Pp-27-29

Sheo, Govind, Chandra, Ram, Karibasappa, G. S., Sharma, C. K. and Singh, I. P. (1998). Research on Spices in NEH Region. ICAR Research Complex for NEH Region, Umiam. Pp. 9-22.

\section{How to cite this article:}

Shil, S., D. Nath and Mondal, J. 2018. Effect of Propagation Methods on Yield Attributes and Economics of Ginger Production under Agro-Climatic Condition of Tripura. Int.J.Curr.Microbiol.App.Sci. 7(05): 3790-3793. doi: https://doi.org/10.20546/ijcmas.2018.705.440 